\title{
Modulation of Radiation Injury in Pregnant Rats by Bone Marrow Transplantation
}

\author{
E. M. Hussein and M. A. Abd Rabu*
}

Radiation Biology Dept., National Centre for Radiation Research and Technology (NCRRT), 29 Nasr City and *Zoology Dept., Faculty of science, Al-Azhar Uni., Egypt.

\begin{abstract}
7 HIS WORK aims to point out the influence of bone marrow transplantation (BMT) in protection of irradiated pregnant rats and suppression of oxidative stress. BMT was administered to rats, $1 \mathrm{~h}$ post gamma irradiation at the dose level of 2 Gy given at the 7th or 14th day of gestation. Rats were examined after 20 days from gestation to detect the physiological parameters of the mother and number of implantation sites and resorptions as well as length of foetuses and tails.

Pregnant rats irradiated at the $7^{\text {th }}$ and $14^{\text {th }}$ day of gestation showed reduction in live foetuses and length of foetuses and their tails and significant decrease in erythrocytes (RBCs), leucocytes (WBCs), haemoglobin content ( $\mathrm{Hb})$, and hematocrite percentage $(\mathrm{Ht})$. Irradiation-induced an elevation in aldosteron and a drop in calcium $(\mathrm{Ca})$. Glutathione levels showed significant decreases in blood while the content of serum thiobarbituric acid reactive substance (TBARS) showed significant increases. Lipid profile exhibited an increase in the concentrations of total cholesterol (TC), triglycerides (TG) and low lipoproteins cholesterol (LDL-C) with a significant decrease in high lipoproteins cholesterol (HDL-C) in both groups.

BMT to irradiated pregnant rats induced significant amelioration in radiation- induced changes. BMT was shown to be effective in reducing physiological disorders and oxidative stress in pregnant rats reflected on minimizing embryonic injuries. Keywords: Rats, gamma rays, bone marrow transplantation.
\end{abstract}

Radiation effects on pregnant rats during embryonic development and foetal growth take place via two systems, physical system of ionizing radiation that involves type, energy and dose of radiation used the quantum mechanisms of energy absorption and the differential response of the various cellular populations in the biological system of the developing embryos and foetuses. The biological system concerns a great number of variables of the dividing, differentiation, proliferating pluripotent cellular populations and the intricate 
sequential modalities involved in the complicated process of embryonic development and foetal growth (Hussien, 2004). Whole body gamma-rays delivered to pregnant rats increased incidence of intrauterine death reduced the rate of growth and caused retarded or abnormal development of the foetal organs (Abu Gabal et al., 1994). While during organogenesis period, radiation exposure caused functional and structure disorders (Inano et al., 1989). Abnormalities in mammals are closely related to the period of development of which radiation was given (Sharma and Saini, 2003). Haematopoietic disorders are one of the most clinical sequels of exposure of mammals to ionizing radiations. Irradiation causes haematopoietic symptoms that include leukocytosis, hyperanemia, lymphopenia and haemolysis (Gridley et al., 2002). Ionizing radiation enhanced lipid peroxidation in cell membrane which contains fatty acids, which in turn increased the cytoplasm membrane permeability to organic substances including enzymes (Bonnefont-Rousselot, 1994).

BMT is used to treat number of cancers and blood diseases; BMT has become one of the most promising treatments for a number of serious illnesses and now saves thousand of patients. BMT contain not only the whole range of marrow myeloid cells, from stem cells to mature cells but stromal cells, including fibroblast precursors, fat cells, endothelial cells, macrophages and their precursors (Burrett and Gordon, 1993) and can be used for tissue repair (Yoon et al., 2005).

BMT causes regeneration in the thymus, spleen and bone marrow (AbuSinna et al., 2005). The aim of this work to investigate the possible protective role of bone marrow transplantation from radiation hazards in the pregnant rats

\section{Materials and Methods}

Mature male and virgin female albino rats of pure strain (Rattus Albinus) ranging from $120-150 \mathrm{~g}$ were obtained from the animal house belonging to NCRRT, Atomic Energy Authority, Egypt. All rats $(n=48)$ were kept under normal conditions of light, temperature and relative humidity, and provided with standard laboratory diet tap water. Irradiation was performed by Canadian

${ }^{137}$ Cesium Gamma cell-40 Biological Irradiator located at NCRRT, Nasr city Cairo, Egypt. Pregnant rats were whole body irradiated at a single dose of 2 Gy

Egypt. J. Rad. Sci. Applic., Vol. 24, No. 1 (2011) 
gamma rays in the $7^{\text {th }}$ or $14^{\text {th }}$ day of gestation and sacrificed on day 20 of gestation (1 day prior delivery). BMT-donors and recipients were chosen of the same inbred strain (isologous or syngenic transplantation). Femur bones were dissected out, cleaned and both ends were chipped by bone nibbling forceps. Bone marrow was blown out into ice cold saline by drawing and expelling it from syringe without needle. $75 \times 10^{\circ} \pm 5$ bone marrow cells were injection i.p. 3 h after irradiation to rats (Declaeva et al., 1972).

Five groups $(n=6)$ of pregnant rats were sorted into: 1- Control group. 2Whole body irradiated pregnant rats at a dose of 2 Gy on day 7 of gestation (late implantation and early organogenesis) (R7) 3- Pregnant rats exposed to 2 Gy of gamma rays on day 7 of gestation and received BMT $75 \times 10^{\circ} \pm 5$ cells by intra peritoneal (i.p.) injection $1 \mathrm{~h}$ post-irradiation $(\mathrm{R} 7+\mathrm{BM})$ 4- Pregnant rats exposed to 2 Gy of gamma rays on day 14 of gestation (organogenesis) (R14) 5Pregnant rats exposed to 2 Gy of gamma rays on day 14 of gestation and received BMT $1 \mathrm{~h}$ post-irradiation $(\mathrm{R} 14+\mathrm{BM})$.

All animals were sacrificed on day 20 of gestation. Number of implantation sites and resorptions besides average length of foetuses and length of their tails were estimated. Animals were slightly anaesthetized with ether and blood was collected by heart puncture. Part of the blood was placed on EDTA for assay of RBSc and WBSc using a haemocytometer, $\mathrm{Ht} \%$ according to Dacie and Lewis (1993), blood haemoglobin content was assayed according to Tietz (1990). Reduced GSH content was measured according to Beutler et al. (1963) and MDA was estimated according to Yoshioka et al. (1979). TC and TG were determined according to Allian et al. (1974) and Richmond (1973). Aldosterone was estimated according to Cartledge and Lawson (2000) and Ca according to Janssen and Helbing (1991).

The results were represented as mean of 6 records \pm standard error (SE) and analyzed using one way analysis of variance followed by Duncan's test (1957). Differences were considered significant at $\mathrm{P}$ value equal $<0.05$.

\section{Results}

The present results showed non-significant decrease in the number of implantation sites in all the treated groups (Table 1). There was a significant 
decrease in the number of live foetuses irradiated on day 7 and 14 of gestation ($31 \%$ and $-42 \%$ ) respectively compared with control group. Nevertheless, nonsignificant decrease in the groups irradiated and treated with BMT on day 7 and 14 of gestation (-6\% and $-11 \%)$, respectively compared with control group.

TABLE 1. Effect of whole body $\gamma$-irradiation (2Gy) and BMT on the number of implantation sites and the live foetuses on days 7 and 14 of gestation.

\begin{tabular}{|c|c|c|}
\hline Groups & Number of live foetuses & Number of implantation sites \\
\hline Control & $9.0 \pm 0.26$ & $9.17 \pm 0.17$ \\
\hline R7 & $6.17 \pm 0.54 *$ & $8.33 \pm 0.49$ \\
\% of change & $-31 \%$ & $-9 \%$ \\
\hline R7+ BM & $8.5 \pm 0.22$ & $8.67 \pm 0.21$ \\
\% of change & $-6 \%$ & $-5 \%$ \\
\hline R14 & $5.3 \pm 0.01 *$ & $8.00 \pm 0.73$ \\
\% of change & $-42 \%$ & $-12 \%$ \\
\hline R14+ BM & $8.0 \pm 0.25$ & $8.00 \pm 0.26$ \\
\% of change & $-11 \%$ & $-13 \%$ \\
\hline \multicolumn{2}{|c|}{-Percentage of change was compared to control. }
\end{tabular}

The results presented in Table 2 . demonstrated a significant drop $(\mathrm{p}<0.05)$ in the body length of foetuses reaching $-23 \%$ in R7 group. This decrease was improved in $\mathrm{R} 7+\mathrm{BM}$ group to reach $-7 \%$ compared to the control group. There is a significant decrease in the body length of foetuses after exposure to gamma rays (2Gy) on day 14 of gestation to reach $-33 \%$ but, the group R14+ BMT showed a slight improvement to reach $-16 \%$.

TABLE 2. Effect of whole body $\gamma$-irradiation (2Gy) and BMT on the body length (cm) of foetuses and their tails and length of tails according to length of body of foetuses in the pregnant rats treated on days 7 and 14 of gestation.

\begin{tabular}{|c|c|c|c|}
\hline Groups & $\begin{array}{c}\text { Length of } \\
\text { foetuses }\end{array}$ & $\begin{array}{c}\text { Length of } \\
\text { foetuses tail }\end{array}$ & $\begin{array}{c}\text { Length of tails according } \\
\text { to length of foetuses body }\end{array}$ \\
\hline Control & $3.43 \pm 0.05$ & $1.37 \pm 0.01$ & 39.94 \\
\hline $\begin{array}{c}\text { R7 } \\
\text { \% of change }\end{array}$ & $\begin{array}{c}2.65 \pm 0.06^{*} \\
-23 \%\end{array}$ & $\begin{array}{c}0.90 \pm 0.04^{*} \\
-34 \%\end{array}$ & 33.96 \\
\hline $\begin{array}{c}\text { R7+ BM } \\
\% \text { of change }\end{array}$ & $\begin{array}{c}3.20 \pm 0.10 \\
-7 \%\end{array}$ & $\begin{array}{c}1.27 \pm 0.06 \\
-7 \%\end{array}$ & 39.68 \\
\hline $\begin{array}{c}\text { R14 } \\
\text { of change }\end{array}$ & $\begin{array}{c}2.31 \pm 0.19^{*} \\
-33 \%\end{array}$ & $\begin{array}{c}0.80 \pm 0.11^{*} \\
-42 \%\end{array}$ & 30.30 \\
\hline $\begin{array}{c}\text { R14+ BM } \\
\text { \% of change }\end{array}$ & $\begin{array}{c}2.88 \pm 0.17^{*} \\
-16 \%\end{array}$ & $\begin{array}{c}1.14 \pm 0.04^{*} \\
-17 \%\end{array}$ & 38.19 \\
\hline
\end{tabular}

Egypt. J. Rad. Sci. Applic., Vol. 24, No. 1 (2011) 
The results presented in Table 2. showed significant drop $(\mathrm{p}<0.05)$ in the tail length of foetuses to $-34 \%$ and $-42 \%$ after exposure to gamma rays (2Gy) on day 7 and 14 of gestation, respectively. Both irradiated and irradiated treated groups showed slight improvements to reach $-7 \%$ and $-17 \%$. Length of foetuses' tail according to the length of their body length recorded 33.96 and 30.30 in groups R7and R14. This percent increased to 39.68 and 38.19 in groups R7+BM and R14+BM compared with the control group (39.94).

TABLE 3. Effect of whole body $\gamma$-irradiation (2Gy) and BMT on aldosterone and Calcium (Ca) on days 7 and 14 of gestation.

\begin{tabular}{|c|c|c|}
\hline Groups & Aldosterone $(\mathrm{pg} / \mathrm{ml})$ & Ca $(\mathrm{mg} / \mathrm{dl})$ \\
\hline Control & $636.26 \pm 80.41$ & $6.69 \pm 1.76$ \\
\hline R7 & $1033.5 \pm 52.18^{*}$ & $4.53 \pm 0.2 *$ \\
$\%$ of change & $62 \%$ & $-32 \%$ \\
\hline R7+ BM & $631.51 \pm 79.16$ & $6.01 \pm 0.18$ \\
\% of change & $-00.74 \%$ & $-10 \%$ \\
\hline R14 & $1130.2 \pm 52.59 *$ & $4.34 \pm 0.4 *$ \\
\% of change & $78 \%$ & $-35 \%$ \\
\hline R14+ BM & $630.49 \pm 79.57$ & $5.90 \pm 0.14$ \\
$\%$ of change & $-0.9 \%$ & $-12 \%$ \\
\hline
\end{tabular}

Legends as in Table 1.

Data in Table 3. showed that aldosterone was significantly increased $(\mathrm{p}<0.05)$ by $2 \mathrm{~Gy}$ gamma irradiation, while Ca was significantly decreased after 7 and 14 days of gestation, respectively compared with the control. While, BMT normalized both of aldosterone and Ca compared to control group.

TABLE 4. Effect of whole body $\gamma$-irradiation (2Gy) and BMT on RBCs, WBCs, Hb and $\mathrm{Ht}$ in the pregnant rats treated on days 7 and 14 of gestation.

\begin{tabular}{|c|c|c|c|c|}
\hline Groups & RBCs $\left(10^{6} / \mathrm{mm}^{3}\right)$ & WBCs $\left(10^{6} / \mathrm{mm}^{3}\right)$ & Hb $(\mathrm{g} / \mathrm{dl})$ & Ht $(\%)$ \\
\hline Control & $5.73 \pm 0.51$ & $5.53 \pm 0.28$ & $13.75 \pm 1.22$ & $41.01 \pm 1.04$ \\
\hline R7 & $3.93 \pm 0.96^{*}$ & $2.53 \pm 0.21^{*}$ & $9.44 \pm 2.31 *$ & $32.4 \pm 1.55^{*}$ \\
$\%$ of change & $-31 \%$ & $-54 \%$ & $-31 \%$ & $-21 \%$ \\
\hline R7+ BM & $5.03 \pm 0.25$ & $5.08 \pm 0.11$ & $12.08 \pm 0.61$ & $40.4 \pm 1.83$ \\
$\%$ of change & $-12 \%$ & $-8.14 \%$ & $-12 \%$ & $-1 \%$ \\
\hline R14 & $4.16 \pm 0.34^{*}$ & $2.94 \pm 0.45^{*}$ & $9.98 \pm 0.82^{*}$ & $32.94 \pm 0.34^{*}$ \\
$\%$ of change & $-27 \%$ & $-47 \%$ & $-27 \%$ & $-20 \%$ \\
\hline R14+ BM & $4.88 \pm 0.30$ & $4.41 \pm 0.44^{*}$ & $11.72 \pm 0.73$ & $39.81 \pm 1.22$ \\
$\%$ of change & $-15 \%$ & $-20 \%$ & $-15 \%$ & $-3 \%$ \\
\hline
\end{tabular}

Legends as in Table 1. 
The results tabulated in Table 4. showed changes in RBCs, WBCs, $\mathrm{Hb}$ content and Ht percent after 2 Gy whole body gamma-rays at day 7 or 14 of gestation and recorded a significant drop $(\mathrm{p}<0.05)$ corresponding to $-31 \%,-54$, $-31 \%$ and $-21 \%$ on day 7 of gestation and $-27 \%,-47 \%$ and $-27 \%$ on day 14 of gestation compared with the control group. While, non significant decrease was recorded in the RBCs count, $\mathrm{Hb}$ content and $\mathrm{Ht}$ percent in the group that receive irradiation together with BMT on day 7 or 14 of gestation compared with the control group. The WBCs count after whole body gamma-rays and BMT showed non significant change $(-8 \%)$ on the $7^{\text {th }}$ day of gestation, while, significant drop (20\%) was still recorded on the $14^{\text {th }}$ day of gestation compared with the control group.

TABLE 5. Effect of whole body $\gamma$-irradiation (2Gy) and BMT on GSH and TBARS on days 7 and 14 of gestation.

\begin{tabular}{|c|c|c|}
\hline Groups & GSH $(\mathrm{mg} / \mathrm{dl})$ & MDA $(\mathrm{n} \mathrm{mol} / \mathrm{ml})$ \\
\hline Control & $28.90 \pm 1.6$ & $70.5 \pm 4.0$ \\
\hline R7 & $13.80 \pm 0.8^{*}$ & $131.14 \pm 11.38^{*}$ \\
$\%$ of change & $-52 \%$ & $86 \%$ \\
\hline R7+ BM & $27.55 \pm 3.64$ & $68.63 \pm 0.73$ \\
$\%$ of change & $-5 \%$ & $-3 \%$ \\
\hline R14 & $13.1 \pm 2.2 *$ & $130.68 \pm 0.72 *$ \\
$\%$ of change & $-55 \%$ & $85 \%$ \\
\hline R14 + BM & $25.5 \pm 2.96$ & $66.97 \pm 0.59$ \\
$\%$ of change & $-12 \%$ & $-52 \%$ \\
\hline
\end{tabular}

Legends as in Table 1.

Data in Table 5. show that blood reduced GSH was significantly depressed $(\mathrm{p}<0.05)$ by $2 \mathrm{~Gy}$ gamma irradiation reaching $-52 \%$ and $-55 \%$ after 7 and 14 days of gestation respectively, compared to control. While, BMT ameliorated that level showing no significant elevation attending $-5 \%$ in R7+BMT group. MDA was significantly ( $\mathrm{p}<0.05$ ) elevated reaching $86 \%$ and $85 \%$ after 7 or 14 day from irradiation of pregnant rats, whereas BMT arrested the elevation to reach $-3 \%$ and $-5 \%$ compared with the control group. The results of this study revealed that, pregnant rats exposed to whole gamma irradiation at $2 \mathrm{~Gy}$ showed significant elevation in the level of TG, TC, and LDL-C by $26 \%, 46 \%$ and $1 \%$ on day 7 and $24 \%, 37 \%$ and $1 \%$ on day 14 of gestation. Significant decrease was observed in HDL-C by $-27 \%$ and $-28 \%$ on days 7 and 14 , respectively. BMT arrested the elevation in TG, TC and LDL-C by $-3 \%,-4 \%$ and $-8 \%$ on Egypt. J. Rad. Sci. Applic., Vol. 24, No. 1 (2011) 
day 7 and $-6 \%,-5 \%$ and $-13 \%$ on day 14 of gestation compared to control group and normalized HDL-C.

TABLE 6. Effect of whole body $\gamma$-irradiation (2Gy) and BMT on blood lipid profile in the pregnant rats treated on day 7 and 14 of gestation.

\begin{tabular}{|c|c|c|c|c|}
\hline Groups & $\begin{array}{c}\text { TG } \\
(\mathrm{mg} / \mathrm{dl})\end{array}$ & $\begin{array}{c}\text { TC } \\
(\mathrm{MG} / \mathrm{dl})\end{array}$ & $\begin{array}{c}\text { LDL-C } \\
(\mathrm{mg} / \mathrm{dl})\end{array}$ & $\begin{array}{c}\text { HDL-C } \\
(\mathrm{mg} / \mathrm{dl})\end{array}$ \\
\hline Control & $81.02 \pm 8.11$ & $75.26 \pm 4.54$ & $24.29 \pm 4.54$ & $34.77 \pm 4.54$ \\
\hline R7 & $102.17 \pm 6.28^{*}$ & $109.62 \pm 7.07^{*}$ & $54.49 \pm 5.78^{*}$ & $25.32 \pm 2.22^{*}$ \\
\% of change & $26 \%$ & $46 \%$ & $1 \%$ & $-27 \%$ \\
\hline R7+ BM & $78.8 \pm 3.4$ & $72.17 \pm 0.38$ & $22.4 \pm 2.06$ & $32.2 \pm 2.5$ \\
\% of change & $-3 \%$ & $-4 \%$ & $-8 \%$ & $-8 \%$ \\
\hline R14 & $100.86 \pm 8.28^{*}$ & $102.8 \pm 3.2^{*}$ & $55.52 \pm 4.84 *$ & $24.9 \pm 2.9^{*}$ \\
\% of change & $24 \%$ & $37 \%$ & $1 \%$ & $-28 \%$ \\
\hline R14+ BM & $76.2 \pm 2.91^{*}$ & $71.3 \pm 0.42^{*}$ & $21.2 \pm 2.90$ & $31.5 \pm 2.9$ \\
\% of change & $-6 \%$ & $-5 \%$ & $-13 \%$ & $-9 \%$ \\
\hline
\end{tabular}

Legends as in table 1.

\section{Discussion}

Physiological alternations take place in the mother during pregnancy. These changes are profound and vital for the successful completion of gestation. Many of these adaptations are hormonally mediated and others are attributed to the effect of gravid uteri (Bocking, 1994). Pregnant rats irradiated on day 7 of gestation showed one complete abortion and the living foetuses were malformed because this stage of pregnancy is sensitive to irradiation as documented by Rousseaux and Blokley (1991). Pregnant rats irradiated on the $14^{\text {th }}$ day of gestation (organogenesis period) showed complete and partial resorptions, diminution in the foetal size and reduction in the growth and length, which agrees with Sharma and Saini (2003). Tail abnormalities and abnormalities of the limbs were prominent upon exposure during the organogenesis period as observed in this study. These changes were also assured by Kim et al. (2001). The degree of damage induced by irradiation depends on the degree of differentiation, state of the cell concerning its cycle, the dose rate and the age of the animal at the time of irradiation (Hussein, 1997 and Salama, 2004). In the present study the number of live foetuses recorded after whole body gamma-rays ( $2 \mathrm{~Gy}$ ) on the $7^{\text {th }}$ or $14^{\text {th }}$ day of gestation showed a significant decrease especially on the $14^{\text {th }}$ day of gestation. These results agree 
with those of Moustafa (2000) and Ramadan (2007), but number of implantation sites showed non significant decrease on the $7^{\text {th }}$ or $14^{\text {th }}$ day of gestation. The decrease in number of foetuses may be due to radiation effect on the proliferating and developmental processes of the embryonic tissue at the stages of organogenesis (Abdel Gawad et al., 2005). Results of the present study showed non significant decrease in the number of implantation sites and the live foetuses in the groups which were irradiated and treated with BM on day 7 or 14 of gestation. The present study showed a significant decrease in the body length of foetuses and their tails taken from irradiated pregnant rats on day 7 or day 14 of gestation. These results agree with those of Hussein (2004). The present study showed non significant decrease in the body length of foetuses and their tails taken from irradiated pregnant rats on day 7 of gestation followed by BMT. Slight improvement was noticed in pregnant rats irradiated on day 14 of gestation and treated with bone marrow.

Irradiation induced significant elevation in serum aldosterone. Gong et al. (1994) showed that aldosterone adapted responsively to the imbalance in water and electrolytes within the body. In accordance with the present results, significant drop in $\mathrm{Ca}$ by irradiation was attributed to inhibitory effect of ionizing radiation on the $\mathrm{Ca}$ channels (Nunia et al., 2007). A correlation exists between embryoliththality and tratogenicity with decrease in Ca level (Ueno et al., 1981). Aldosterone, opens voltage dependant Ca channels, promotes the reabsorption of $\mathrm{Na}$ in the distal tubules of the kidney resulting in $\mathrm{K}$ secretion along with $\mathrm{Na}$ retention, which controls the circulating blood volume (Cartledge and Lawson, 2000). This might explain the decrease in foetus and tail length. BMT normalized aldosterone and $\mathrm{Ca} 1 \mathrm{~h}$ post-irradiation compared to irradiated group as detected by Zhuo et al. (2006), which coincides with the present findings.

Haematopoietic system is known to be one of the most radiosensitive and its damage may be critical for the survival due to haematopoietic syndrome. The survival after irradiation is really a result of recovery of several target system as bone marrow, gastrointestinal tract, skin and haemostatic system (Tukovet et al., 2002). The so-called haematopoietic system death is a result of infection due to the impairment of the immune system (Chen et al., 2006). In the present Egypt. J. Rad. Sci. Applic., Vol. 24, No. 1 (2011) 
study, whole body $\gamma$-irradiation of pregnant rats at $2 \mathrm{~Gy}$ induced many disorders in the haematological parameters as manifested by the drop in RBCs, WBCs count, $\mathrm{Hb}$ content and $\mathrm{Ht}$ percent on day 7 or 14 of gestation. The present results indicated that RBCs count decreased in the pregnant rats due to ionizing radiation and the release of their enzymes cannot be excluded as causative factors for rise of these enzymes (Azab et al., 2001) and might be attributed to increased permeability of cell membrane which caused osmotic swelling leading to erythrocyte haemolysis (Kafafy et al., 2001 \& 2006 and Hussein, 2008). Ashry et al. (2009) concluded that the decrease in leucocytic count may be attributed to short life span of circulating leucocytes and the radio sensitivity of their precursors in the haematopoietic organs. Irradiation caused lymphopenia and neutropenia and that was attributed to the direct damage of the mature WBCs, the inhibition of mitotic division of progenitor's cells and/or radiation induced apoptosis in addition to the marked reduction in cell division (Szumiel, 1994). A significant decrease in $\mathrm{Hb}$ content attributed to ionizing radiation possibly caused retardation in corporation of iron in addition to a decrease in $\mathrm{Hb}$ binding to erythrocyte membrane (El Tahawy et al., 2008).

In addition, to direct radiation-induced damage to cells concerned by production and activation of haemostatic factors, radiation induced inflammation, which in turn modulates the homeostatic system by induction the coagulation and fibrinolytic systems (Salama et al., 2007). Various mechanisms such as prevention of damage through inhibition of free radical generation or its intensified scavenging, enhancement of DNA and membrane repair , replacement of dead haematopoietic and other cells and stimulation of immunecells activities are considered important approaches for radio-protection and radio- recovery (Nubel et al., 2006). Results of the present study showed that bone marrow transplantation post-irradiation showed no significant decrease in RBCs count on the $7^{\text {th }}$ or $14^{\text {th }}$ day of gestation. This result agrees with those of Morimoto et al. (1995) who recorded normalization of RBCs count in irradiated BMT animals; this may be due to replacement or restoration of injured haematopoietic tissue components. In addition, treatment with bone marrow cells showed increased haemoglobin concentration. These results are in agreement with those of Abdel Samad (1996) and Kafafy et al. (2006) who mentioned that irradiated animals treated with BMT showed no significant 
decrease in white blood cells count followed by a slight improvement on the $14^{\text {th }}$ day of gestation.

Bone marrow transplantation induced a slight improvement in white blood cells count as indicated by Abu El Enein et al. (1992). They concluded that the restoration of total white blood cells count in irradiated mice treated with bone marrow was better than those treated with the spleen homogenate.

In the present study, significant decrease of glutathione and significant increase in MDA was observed in irradiated groups compared with control groups. GSH is a versatile protector and executes its radio protective function through free radicals scavenging, restoration of the damage molecules by hydrogen donation, reduction of peroxides and maintenance of protein thiol in the reduced state (Hussein, 2008). In the current study, TBARS content exhibit a significant increase in pregnant rats exposed to2Gry gamma rays this elevation is attributed to, ionizing radiation induced lipid peroxidation through the generation of ROS which attack the polyunsaturated fatty acids constituents of the cell membrane and other cell biomolecuels, initiates a self- perpetuating chain reaction that yield a wide range of cytotoxic products such as TBARS (Gutteridge, 1995). BMT post irradiation is shown to rise the erythropoietic activity in both bone marrow and spleen (De Rooij et al. 2002) thus elevation in red blood cells, the important source of GSH , ameliorated the GSH deplation in blood and hence oxidative stress (Ashry and Hussein, 2007).

In the current study, significant elevations in serum TG, TC and LDL-C was observed in irradiated pregnant rats. This increase may be a result of increased breakdown of lipids and mobilization of free fatty acids from the prepheral depots, whereas the HDL-C level showed significant decrease. Elkafif et al. (2003) reported that increased level of serum CT fractions was probably due to its release from tissue, destruction of cell membrane and increased rate of TC biosynthesis in the liver and other tissues. The increase in plasma triglycerides may be attributed to inhibition of the activity of lipoprotein lipase. The results were consistent with the observation of Sedlakova et al. (1986), who mentioned that lipoprotein lipase activity decreases post irradiation exposure in adipose tissues giving rise to hypertriglyceridemia (Derval and Sichevskaia, 2000; El Tahawy et al., 2008). BMT ameliorate the elevation of TG, TC and

Egypt. J. Rad. Sci. Applic., Vol. 24, No. 1 (2011) 
LDL-C. BMT was shown to be effective in reducing physiological disorders in pregnant rats reflected on minimizing embryonic injuries.

\section{Reference}

Abdel Gawad, I., Badr, H. and Shabon, M. (2005) Physiological effect of natural humic acid during pregnancy on fetuses and natural alterations induced by irradiation in rats. Isotope Rad. Res., 37, 749.

Abdel Samad, N. (1996) Bone marrow transplantation as a curative treatment of radiation injury to certain haematological levels in rats. M. Sc. Thesis, Faculty of Science, Cairo Univ.

Abu El Enein, M., Abdeen, M., Gadallah, F., El-Hefnawy, N., Ziada, A., Nasrat, F. and Shaker, H. (1992) Comparative analysis of transplantation of combined bone marrow and splenic cells versus either bone marrow or splenic cells in heavily irradiated mice. Egypt. J. Haemat., 17, 103.

Abu Gabal, H., Eid, F. and Gaber, S. (1994) Combined effect of radiation and polytrin insecticide on the development of rat embryo. Egypt. J. Rad. Sci. Appl., 7, 221.

Abu Sinna, G., Kafafy, Y., Nassar, A. and Salaman, M. (2005) Synergistric effect of bone marrow transplantation and brady kinin potentiating factor isolated from venom on thymus and spleen of sublethally irradiated Guinea pig. Egypt. J. Rad. Sci. Applic., 18, 249.

Allian, C. A., Poom, S., Chan, C. S. G., Richmond, W. and Fu, P. C. (1974) Enzymatic determination of total serum cholesterol. Clin. Chem., 20, 470.

Ashry, O. and Hussein, E. (2007) Radioprotective potency of Ginseng on some haematopoietic and physiological parameters in irradiated rats. Egypt. J. Rad. Sci. Appli., 20, 39.

Ashry, O., Hussein, E. and Salama, S. (2009) Boosting of antioxidant defense by interferon-alfa in irradiated bone marrow transplanted rats. Egypt. J. Rad, Sic. Applic., 22, 19.

Azab, K.; Saada, H. and Said, O. (2001) The action of long term treatment with coenzyme $\mathrm{Q}_{10}$ in minimizing radiation-induced damage. Arab. J. Nucl. Sci. Appli., 34, 283.

Beutler, E., Duron, O. and Kelly, B. (1963) Improved method for the determination of blood glutathione. J. Lab. and Clin. Med., 61, 882.

Bocking, A. (1994) Text Book of Foetal Physiology. Eds. Thorburn, G.D. and Hardings R. Oxford Univ. Press. P: 397

Bonnefont-Rousselot, D. (1994) Irradiation of cell membranes. J. De ChimiePhysique-et-Physico Chimie-Biologique., 91, 968.

Egypt. J. Rad. Sci. Applic., Vol. 24, No. 1 (2011) 
Burrett, A. and Gordon, M. (1993) Bone Marrow Disorders. The Biological Basis of Treatment. $2^{\text {nd }}$, Blackwell Scientific Publications. Oxford.

Cartledge, S. and Lawson, N. (2000) Aldosterone and renin measurements. Ann. Clin. Biochem., 37, 278.

Chen, Y.M., Lin, S. L., Chiang, W. C., Wu, K. D. and Tsai, T. J. (2006) Pentoxifylline ameliorates proteinuria through suppression of renal monocyte chemoattractant protein-1 in patients with proteinuric primary glomerular diseases. Kidney Int., 15, 123.

Dacie, S. T. and Lewis, S. M. (1993) Practical Haematology. ELBS and Churchill, Levingston. London. Chapt. 5, p. 37.

De Rooji, D. G., Van de Kant, H. J., Dol, R., Wagemaker, G. and Van Buul, P. P. (2002) Long-term effects of irradiation before adulthood on reproductive function in the male Rhesus monkey. Biol. Reprod., 66, 486.

Decleave, A., Gerber, G. B., Leonard, M., Lambient-Collier, M., Sassen, A. and Maisin J. R. (1972) Regeneration of thymes, spleen and bone marrow in Xirradiated AKR mice. Rad. Res., 51, 318.

Duncan, D. (1957) Multiple range tests for correlated and hetroscedastic means. Biometrics, 13, 164.

El Tahawy, N. Salama, S. and Ashry, O. (2008) The modulatory role of vitis vinifera in oxidative stress and carbohydrate metabolism of irradiated rats. Arab. J. of Nuclear Sci. and Appli., 41, 262.

El-Khafif, M., Ragab, M., Eldawy, H. and Tawfik, S. (2003) Effect of taurine treatment on some biochemical parameters in gamma irradiated mice. Environ. Sci., 6, 393.

Gong, S., Fan, B. and Zhou, J. (1994) Effects of large dose x-irradiation on function of rennin-angiotensin-aldosterone system. Med. Sci., 20, 136.

Gridely, D. Pecaut, M. Dutta Roy, R. and Nelson, G. (2002) Dose and dose rate effects of whole body proton irradiation on leukocyte populations and lymphoid organs. Immunol. Lett., 80, 55.

Gutteridge, M. C. J. (1995) Lipid peroxidation and antioxidants as biomarkers of tissue damage. Clin. Chem., 41, 1819.

Hussein, E. (1997) Effects of some food pollutants on pregnant rats and their fetuses. M.Sc. Thesis, University College for women, Ain Shams University

Hussein, E. (2004) Natural protection of bone marrow transplantation to gamma irradiated pregnant rats in view of better restoration of certain vital organ functions. Ph.D. Thesis, Faculty of Science, Ain Shams Univ.

Hussein, E. (2008) Modulatory role of Arabic gum in gamma rays induced damages in rats. J. Rad. Res. Appl. Sci., 1, 427.

Egypt. J. Rad. Sci. Applic., Vol. 24, No. 1 (2011) 
Inano, H. Suzuki, K. and Ishiiohba, A. (1989): Steroid hormone production in testis, ovary and adrenal gland of immature rats irradiated in utero with $\mathrm{Co}^{60}$. Radiat. Res., 117, 293.

Jacquet, P. and Grinfeld, S. (1990) Influence of some methodological factors on the radiosensitivity of the mouse zygot. Teratology, $\mathbf{4 2}, 453$.

Janssen, J. W. and Helbing, A. R. (1991) An improvement of the routine calcium determination in serum. Eur. J. Clin. Biochem., 29, 197.

Kafafy, Y. Abu Gabal, H. Roushdy, H. Abu Sinna, G. and Ashry, O. (2001) Bone narrow transplantation controlling hormonal and structural changes in radiation exposed pregnant mice and their developing embryos. Egypt. $J$. Rad. Sci. Appli., 14, 1

Kafafy, Y. Roushdy, H. El Beih, H. and Hussein, E. (2006) Propolis maintaining the restrorative role played by bone marrow transplantation in pregnant rats exposed to whole body gamma-irradiation. J. Rad. Sci. Appli., 19, 353.

Kim, S. Lee, J. Oh, H. Kim, S. Lee, S. (2001) Dependence of malformation upon gestational age and exposed dose of gamma radiation. J. Rad. Res., 42, 255.

Morimoto, M. Kanno, H Asai, H. Tsujimura, T. fujii, H. Moriyama, Y. Kasugai, T. Hirono, A. Ohba, Y. Miwa, S. and Kitamura, Y. (1995) Pyruvate Kinase deficiency of mice associated with nonspherocytic hemolytic anemia and cure of the anemia by marrow transplantation without host irradiation. Blood, 86, 4323.

Moustafa, N. (2000) The protective effect of Nigella Sativa on maternally $\gamma$-irradiated mice embryos. Egypt. J. Zoo., 35, 287.

Nubel, T., Damrot, J., Wynand, P., Kaina, R. and Fritz, G (2006) Lovastatin Protects human endothelial cells from killing by ionizing radiation without impairing induction and repair of DNAdouble-strand breaks. Clin. Cancer Res., 12, 933.

Nunia, V., Sncheti, G. and Goyal, P. K. (2007) Protection of Swiss albino mice against whole-body gamma irradiation by diltiazem. British J. Radiol. 80, 77.

Ramadan, F. (2007) Efficacy of wheat germ oil in alleviating certain disorders induced by aspirin administration and / or X-rays in pregnant albino rats and their fetuses. Egypt. J. Rad. Sci. Applic., 20, 497

Richmond, W. (1973) Preparation and properties of the cholesterol oxidase from nacordia sp. and its application to the enzymatic assay of total cholesterol in serum. CLIN Chem., 19, 1350.

Rousseaux, C. and Blokley, P. (1991) The fetus. In Handbook of Toxilogic Pathology. Haschex, W.M. and Rousseaux, C. Academic Press Inc. 938.

Egypt. J. Rad. Sci. Applic., Vol. 24, No. 1 (2011) 
Salama, S. (2004) Biological studies on the role of green tea as antioxidant in protecting pregnant female rats against radiation hazards.Ph.D. Faculty of Sci., Zagazig, Univ

Salama, S. Ashry, O. and Hussein, E. (2007) Concomitant effect of ciprofloxacin and echinaoea counteracting severity of radiation damage in rats. Egypt. J. Rad. Sci. Applic., 20, 365.

Sedlakova, A., Borikova, K. andAhlers, T. (1986) Changes in lipoprotein lipase activity in the adipose tissue and heart on non-lethally X-irradiation rats. Physiol. Bohemoslov., 35, 400.

Sharma, P. and Saini, M. (2003) Modification of radiation induced mortality by cysteamine, MPG and their combination in Swiss albino mice. Ind. J. Nuc. Med., 18, 12.

Szumiel, I. (1994) Ionizing radiation induced-cell death. Int. J. Rad. Biol., 66, 329,

Tietz, N. (1990) Text book of Clinical Chemistry. $2^{\text {nd }}$ ed . Saunders Companey. p.566.

Tukov, P., Shaphranskiy, I. andKicva, N. (2002) Comarison of indices of peripheral bkood and external beam radiation dose in men who eliminated the sequences of Chernobyl accident. Med. Rad. Res. Safety, 6, 27.

Ueno, K., Masumura, H., Kitagwa, H. and Sakai, T. (1981) Hypocalcemic effect of acetylsalicylic and in rats. J. pharmacobiodyn., 4, 229.

Yoon, Y. S., Wecka, A., Heyd, L., Park, J. S., Thebuchava, T., Kusano, K., Hanley, A., Scadova, H., Quin, G., Cha, D. H., Johanson, K. L., Aikawa, R., Arahara, T. and Losordo, D. W. (2005) Clonally expanded novel multipotent stem cell's from human bone marrow regulate myocardium after myocardial infarction. J. Clin. Invest., 115, 326.

Yoshioka, T., Kawada, K., Shimada, T. and Mori, M. (1979): Lipid peroxidation in maternal cord blood and protective mechanism against activated oxygen toxicity in blood. Am. J. Obstet. Gynecol., 135, 372.

Zhuo, J. L., Li, X. C., Garvin, J. L., Navar, L. G. and Carretero, O. A. (2006) Intracellular ANG II induces cytosolic $\mathrm{Ca} 2+$ mobilization by stimulating intrac ellular AT1 receptors in proximal tubule cells. Am. J. Physiol. Renal Physiol., 290, 1382.

(Received: 04/10/2011;

accepted: 03/11/2011)

Egypt. J. Rad. Sci. Applic., Vol. 24, No. 1 (2011) 


$$
\begin{aligned}
& \text { تعـديل الضـرر الاشـعاعى باسـتخدام زراعـة نخــاع العظــام في }
\end{aligned}
$$

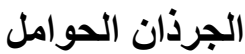

$$
\begin{aligned}
& \text { الهام مصطفى حسين ومرفت احمد عبد ربة" }
\end{aligned}
$$

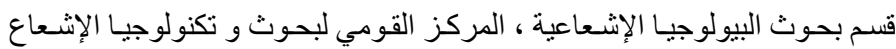

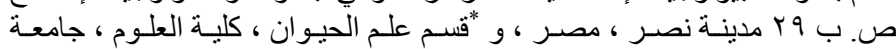

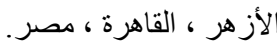

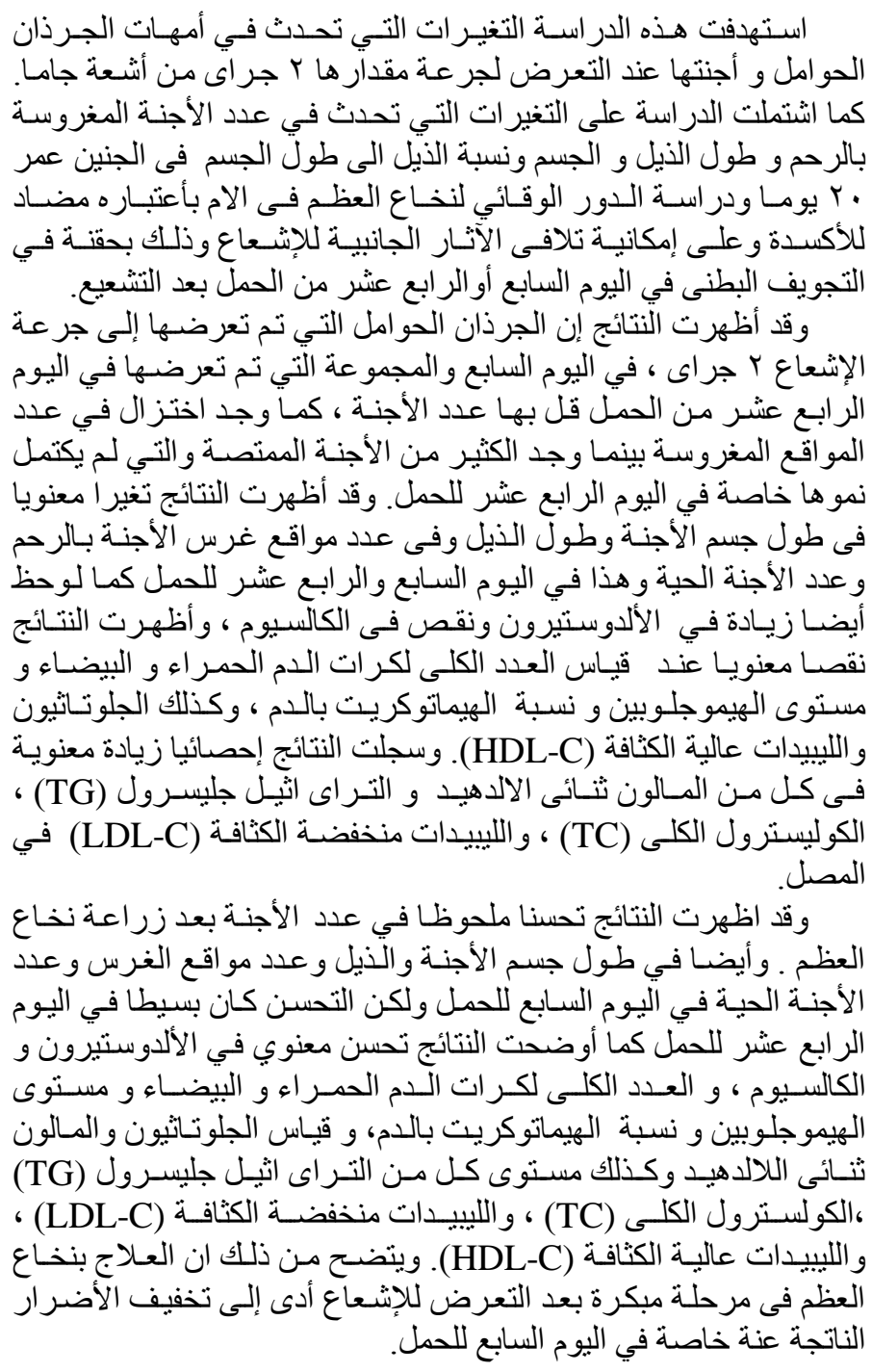

Egypt. J. Rad. Sci. Applic., Vol. 24, No. 1 (2011) 